\title{
A study on the effect of green marketing on consumers' purchasing intention
}

\author{
Mehdy Fallah ${ }^{a^{*}}$ and Mohammad Reza Ebrahimi ${ }^{\mathrm{b}}$
}

${ }^{a}$ Department of Management and Accounting, Ershad-Damavand Higher Education Institute, Damavand, Iran ${ }^{b}$ Department of Management and Accounting, Shahid Beheshti University, Tehran, Iran

\section{H R O N I C L E}

\begin{tabular}{l}
\hline Article history: \\
Received October 28, 2013 \\
Received in revised format \\
25 November 2013 \\
Accepted 22 January 2014 \\
Available online \\
January 25 2014 \\
\hline Keywords: \\
Green Management \\
Consumers'purchasing intention \\
Dairy industry \\
\hline
\end{tabular}

\section{A B S T R A C T}

During the past two decades, there have been significant damages on environment such as ozone layer depletion, global warming effects, etc. and people are getting more concerned about taking necessary actions to help environment. The purpose of this paper is to study the effect of green marketing on consumers' purchasing intention in dairy industry. The proposed study designs a questionnaire and distributes it among 154 randomly selected people who purchase dairy products in four different regions of city of Babol, located in north region of Iran. Using structural equation modeling, the study has detected that green marketing influences on consumers' purchasing intention, positively.

\section{Introduction}

During the past two decades, there have been significant damages on environment such as ozone layer depletion, global warming effects, etc. and people are getting more concerned about taking necessary actions to help environment (Cao, 2011; Dangelico \& Pontrandolfo, 2010; Peattie \& Charter,1994). According to Singh and Pandey (2012), "Green revolution, going green, environmental protection, sustainable life style, sustainable development, protecting our earth and many more has become a natural phenomenon in our everyday life". Boztepe (2012) presented some detailed information about the impact of green marketing on customers purchasing behaviors. She first discussed the issues associated with environment as the one of the reasons that the green marketing emerged and then she performed an empirical investigation on 540 consumers in Istanbul. According to her survey, environmental awareness, green product features, green promotion activities and green price influenced on green purchasing behaviors of the consumers in positive way. 
Mostafa (2009) applied self-organizing maps (SOM) to study the impact of different psychographic and cognitive factors influencing on green consumption in Kuwait. They reported that major variables influencing on green consumption were associated with altruistic values, environmental concern, environmental knowledge, skepticism towards environmental claims, attitudes toward green consumption, and intention to buy green products.

Borin et al. (2011) investigated the effect of different levels of environmental information on key consumer metrics and made an assessment on environmentally benign products against those that have negative environmental effects. They reported that consumer perception of product quality, value, and purchase intentions would not differ substantially between products with positive environmental messages and those without any message. Products with positive environmental messages were considered better than products with negative environmental messages. Prakash (2002) concentrated on promoting products by considering claims about their environmental attributes or about firms that manufacture and/or sell them. He also concentrated on product and pricing issues. Chan et al. (2006) explore how various types of environmental claims could influence on the communication effectiveness of environmental advertising and reported that environmental claims enhance the communication effectiveness of advertisements. Rivera-Camino (2007) investigated the effect of stakeholders on green marketing strategy (GMS).

\section{The proposed study}

The purpose of this paper is to study the effect of green marketing on consumers' purchasing intention in dairy industry. The proposed study designs a questionnaire and distributes it among some randomly selected people who purchase dairy products in four different regions of city of Babol, located in north region of Iran. The sample size is calculated as follows,

$$
N=Z_{\alpha / 2}^{2} \frac{p \times q}{e^{2}},
$$

where $N$ is the sample size, $p=1-q$ represents the probability, $z_{\alpha / 2}$ is CDF of normal distribution and finally $\varepsilon$ is the error term. For our study we assume $p=0.5, z_{\alpha / 2}=1.96$ and $e=0.05$, the number of sample size is calculated as $N=154$. We have distributed 200 questionnaires and managed to collect 173 properly filled ones. The proposed study has applied Kolmogorov-Smirnov in order to understand whether the data are normally distributed or not, which yields a value of 0.86 and it means the data are normally distributed. Therefore, we use Pearson correlation test to examine the relationship between different components of the survey. Fig. 1 summarizes personal characteristics of the participants. As we can observe from the results of Fig. 1, most participants are highly educated.

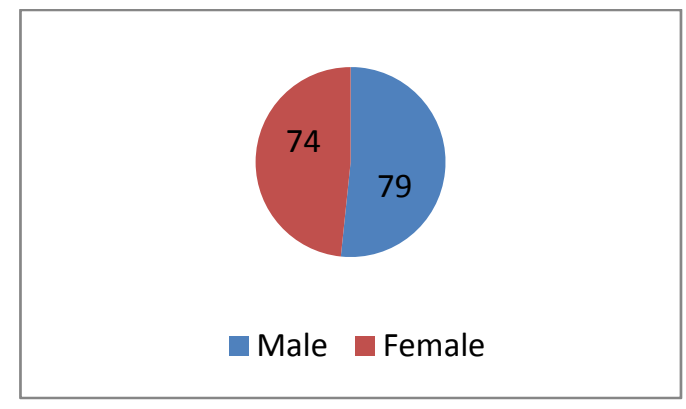

Gender

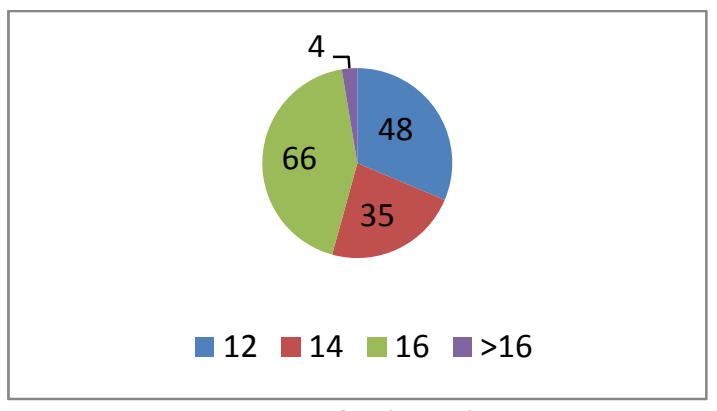

Years of education

Fig. 1. Personal characteristics of the participants 
The proposed study of this paper uses structural equation modeling as well as linear regression techniques to verify the hypotheses of this survey. The primary question of the survey is to learn the effects of green marketing planning on consumers' purchasing intention. The implementation of structural equation modeling (SEM) has been accomplished on LISREL software package.

\section{The results}

We first present details of our findings on SEM implementation. Fig 2 demonstrates the summary of our findings.

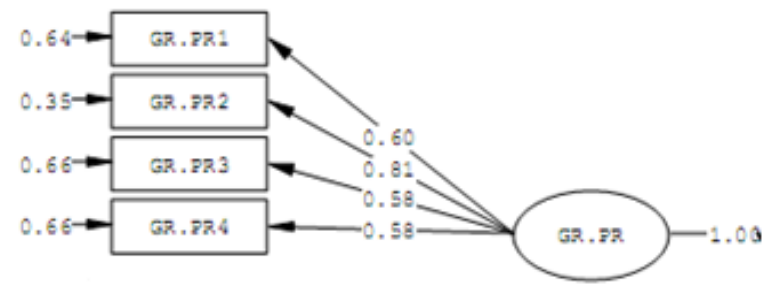

The results of the effects of marketing mix

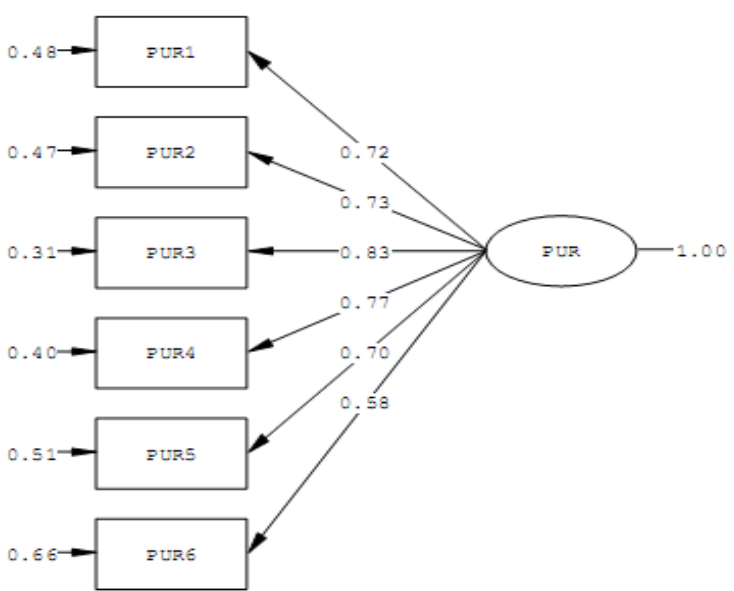

The results of the effects of green purchasing

Fig. 2. The effects of standard values for marketing mix and green purchasing

Note that all statistical observations such as RMSEA, GFI, GGFI, etc. are within acceptable levels and we can confirm that green marketing planning influences positively on consumer purchasing intention. We have also performed regression analysis to find the effects of green marketing planning on purchasing intention and Table 1 summarizes the results of some basic statistical observations.

\section{Table 1}

The summary of basic statistical observation on regression analysis

\begin{tabular}{cccccc}
\hline Model & R & R Square & Adjusted R Square & Std. Error of the Estimate & Durbin-Watson \\
\hline 1 & $.978^{\mathrm{a}}$ & .966 & .904 & .30826 & 2.327 \\
\hline
\end{tabular}

As we can observe from the results of Table 1, adjusted R-Square is approximately equal to 0.966, which states that the dependent variable, consumers' purchasing intention, is highly described by green marketing planning. In addition, Durbin-Watson is within an acceptable limit, which validates the overall survey. Table 2 shows details of our survey on ANOVA test.

Table 2

The summary of ANOVA test

\begin{tabular}{ccccccc}
\hline & Model & Sum of Squares & df & Mean Square & F & Sig. \\
\hline \multirow{2}{*}{1} & Regression & 2.783 & 1 & 2.783 & 29.288 & $.022^{\text {a }}$ \\
& Residual & .190 & 2 & .095 & & \\
\cline { 2 - 7 } & Total & 2.973 & 3 & & & \\
\hline
\end{tabular}

The result of ANOVA test also confirms that there is a linear relationship between independent variable and dependent variable. Table 3 shows details of regression analysis. 
Table 3

The summary of regression analysis

\begin{tabular}{|c|c|c|c|c|c|c|}
\hline & \multirow[b]{2}{*}{ Model } & \multicolumn{2}{|c|}{ Unstandardized Coefficients } & \multirow{2}{*}{$\begin{array}{c}\text { Standardized Coefficients } \\
\beta\end{array}$} & \multirow[b]{2}{*}{1} & \multirow[b]{2}{*}{ Sig. } \\
\hline & & $\beta$ & Std. Error & & & \\
\hline \multirow[t]{2}{*}{1} & (Constant) & -.395 & .768 & & -.514 & .711 \\
\hline & VAR00002 & 1.212 & .211 & .933 & 5.412 & .031 \\
\hline
\end{tabular}

Based on the results of Table 3, the standard coefficient associated with the effect of green marketing planning on consumers' purchasing planning is $\beta=0.933$, which means an increase of one unit in green marketing planning also increases consumers' purchasing intention.

\section{Conclusion}

In this paper, we have presented an empirical investigation to study the effect of green marketing planning on purchasing intention on dairy products in one of Iranian cities. The proposed study has implemented structural equation modeling as well as linear regression technique to study the relationships between green marketing planning and consumers' purchasing intentions. The results have confirmed that consumers cared about environment and would be more interested in purchasing products, which are environment friendly.

\section{Acknowledgement}

The authors would like to thank the anonymous referees for constructive comments on earlier version of this paper.

\section{References}

Borin, N., Cerf, D. C., \& Krishnan, R. (2011). Consumer effects of environmental impact in product labeling. Journal of Consumer Marketing, 28(1), 76-86.

Boztepe, A. (2012). Green marketing and its impact on consumer buying behavior. European Journal of Economic and Political Studies, 5(1), 5-21.

Cao, X. (2011). Does It Pay to be Green? An Integrated View of Environmental Marketing with Evidence from the Forest Products Industry in China (Doctoral dissertation, University of Washington).

Chan, R. Y., Leung, T. K. P., \& Wong, Y. H. (2006). The effectiveness of environmental claims for services advertising. Journal of Services Marketing, 20(4), 233-250.

Dangelico, R. M., \& Pontrandolfo, P. (2010). From green product definitions and classifications to the Green Option Matrix. Journal of Cleaner Production, 18(16), 1608-1628.

Mostafa, M. M. (2009). Shades of green: A psychographic segmentation of the green consumer in Kuwait using self-organizing maps. Expert Systems with Applications, 36(8), 11030-11038.

Peattie, K., \& Charter, M. (1994). Green marketing. The marketing book, 5, 726-755.

Prakash, A. (2002). Green marketing, public policy and managerial strategies. Business Strategy and the Environment, 11(5), 285-297.

Rivera-Camino, J. (2007). Re-evaluating green marketing strategy: a stakeholder perspective. European Journal of Marketing, 41(11/12), 1328-1358.

Singh, P. B., \& Pandey, K. K. (2012). Green marketing: Policies and practices for sustainble development. Integral Review, 5(1), 22-30. 